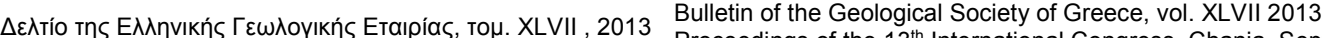
Proceedings of the $13^{\text {th }}$ International Congress, Chania, Sept.

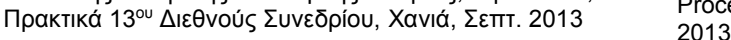

\title{
CHEMOSTRATIGRAPHY OF THE TOARCIAN OCEANIC ANOXIC EVENT FROM THE IONIAN ZONE, GREECE
}

\author{
Kafousia N. ${ }^{1}$, Karakitsios V. ${ }^{1}$, Mattioli E. ${ }^{2}$ and Jenkyns H. C. ${ }^{3}$ \\ ${ }^{I}$ National and Kapodistrian University of Athens, Faculty of Geology and Geoenvironment, De- \\ partment of Hist.Geology - Paleontology,nkafousia@geol.uoa.gr,vkarak@geol.uoa.gr, \\ ${ }^{2}$ Laboratoire de Géologie de Lyon UMR 5276 CNRS, Université Lyon 1, ENS Lyon, Campus de la \\ Doua, Bâtiment Géode, F-69622 Villeurbanne Cedex, France, emanuela.mattioli@univ-lyon1.fr \\ ${ }^{3}$ Department of Earth Sciences, University of Oxford, South Parks Road OXFORD OX1 3AN, \\ United Kingdom,Hugh.Jenkyns@earth.ox.ac.uk
}

\begin{abstract}
A global perturbation in the carbon cycle has been recorded in the Early Toarcian $(\sim 183 \mathrm{Ma})$ and is marked by enhanced organic-carbon burial and mass extinction. It is also associated with high palaeotemperatures, both positive and negative excursions in carbon-isotope ratios, and the development of anoxic to euxinic conditions in marine environments: together these phenomena have been designated as constituting an Oceanic Anoxic Event. Here we provide a high-resolution, multiproxy biostratigraphic and chemostratigraphic study from a section that belongs to the central Ionian Zone in Greece. Calcareous nannofossil distribution, as well as the TOC, $\delta^{13} C_{\text {carb }}$ and $\delta^{13} C_{\text {org }}$, have all been determined. The nannofossil zones NJT $5 b$, NJT 6 and NJT 7 have been recognized in the section. In the NJT $5 b$ zone a small positive excursion in TOC and negative excursion in $\delta^{13} C_{\text {carb }}$ is recorded, tentatively assigned to the Pliensbachian/Toarcian boundary. In the NJT 6 zone, the main negative carbon-isotope excursion characteristic of this interval is developed, associated with a relative increase in TOC. The difference in this section, compared with sections from the Pindos Zone but in common with sections elsewhere, is the record of a positive excursion in the NJT 7 zone in both organic and carbonate carbon isotopes. This study offers new biostratigraphic and geochemical data for the Ionian Zone, and further illustrates the impact of Toarcian Oceanic Anoxic Event in the Tethyan region.

Key words: Jurassic, total organic carbon, carbon isotopes, biostratigraphy, geochemistry.
\end{abstract}

\section{$\Pi \varepsilon \rho i ́ \lambda \eta \psi \eta$}

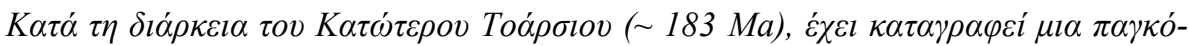

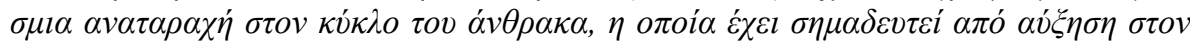

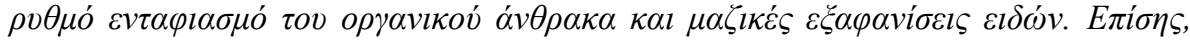

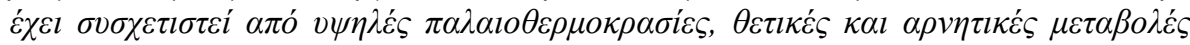

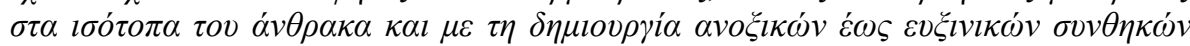

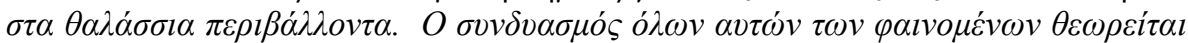

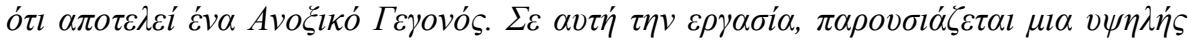

$\underline{\text { XLVII. No } 2-825}$ 


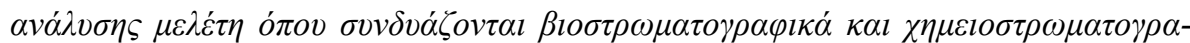

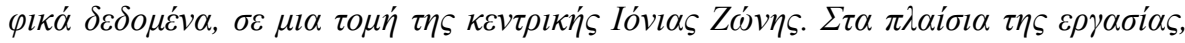

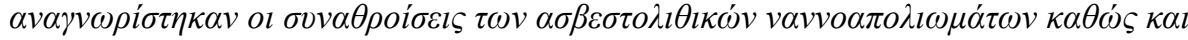

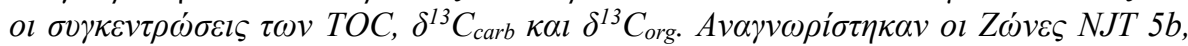

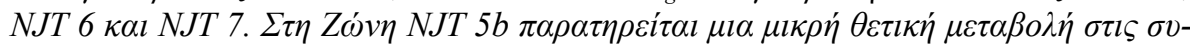

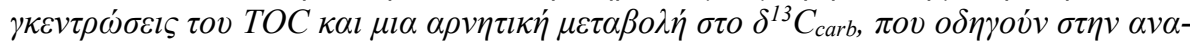

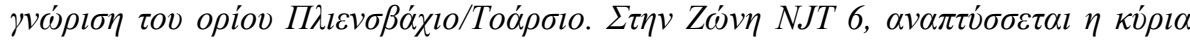

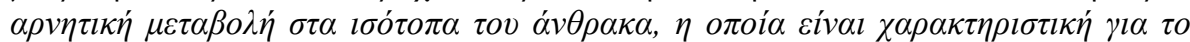

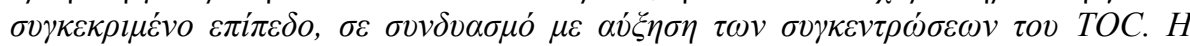

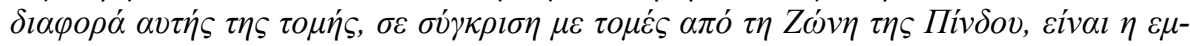

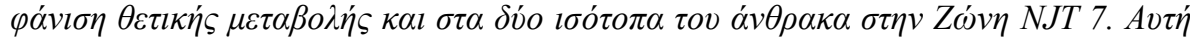

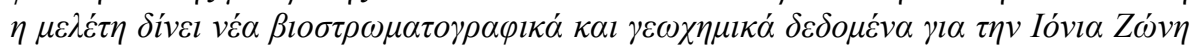

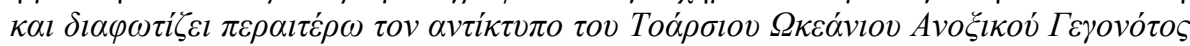

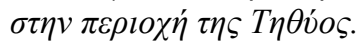

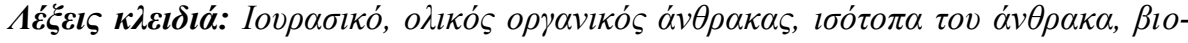

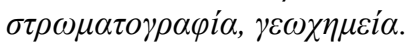

\section{Introduction}

The Toarcian Oceanic Anoxic Event (T-OAE) constitutes one of the most profound environmental changes of the Mesozoic Era (Jenkyns, 1988). Marine depositional settings across the globe, show evidence for global warming (Bailey et al., 2003; Jenkyns, 2003; Suan et al., 2008), mass extinction (Little and Benton, 1995; Wignall, 2001) and probable ocean acidification (Hermoso et al., 2012; Hönisch et al., 2012; Trecalli et al., 2012). A major perturbation in the global carbon (Cohen et al., 2007) and sulphur cycle (Gill et al., 2011; Newton et al., 2011) during the Toarcian has been recorded. The carbon perturbation is marked by a negative excursion in carbon isotopes interrupting an overarching positive trend, that has been recorded in terrestrial wood (Hesselbo et al., 2000; Hesselbo et al., 2007; Al-Suwaidi et al., 2010), marine organic matter and carbonate (Jenkyns and Clayton, 1986; Suan et al., 2008; van Breugel et al., 2006; Woodfine et al., 2008).

In this paper, we present biostratigraphical (calcareous nannofossils) and geochemical (wt\% TOC, $\delta^{13} \mathrm{Ccarb}$, and $\delta^{13} \mathrm{Corg}$ ) data from the Toarcian sediments of the central Ionian Zone (Petousi section), a marine basin that constituted part of the southern Tethyan margin (Bernoulli and Renz, 1970). Age equivalent deposits in Greece have recently chemostratigraphically studied in Pindos Zone (Karakitsios et al., 2010; Kafousia et al., 2011), corresponding to a deep-sea ocean-margin basin that formed in mid-Triassic times along the northeastern part of Apulia.

\section{Geological Setting}

The Ionian Zone of NW mainland Greece is one of most external Hellenides (Paxos Zone, Ionian Zone, Gavrovo Zone; Aubouin, 1959). This domain corresponds to the southern passive continental margin of the Neotethys Ocean. This Ocean's opening started in Early Mesozoic while its closure took place during the Late Mesozoic-Early Cenozoic (Karakitsios, 1992, 1995; Laubscher and Bernoulli, 1977). The Ionian Zone constitutes of rocks that range from Triassic evaporites through a varied series of Jurassic to Upper Eocene mixed carbonate-siliciclastic-siliceous sediments, overlain by Oligocene flysch. During the Early Jurassic, northwestern Greece was covered by a vast carbonate platform (IGRS-IFP, 1966; Bernoulli and Renz, 1970; Karakitsios, 1992, 1995). In the Pliensbachian, extensional stresses that are related to the opening of the Neotethys Ocean, began to act in the area and caused the differentiation of the Ionian Zone from the adjacent Zones (Karakitsios, 1992, 1995). These Zones (Paxos and Gavrovo) remained carbonate platforms, while the Ionian Zone became an area of strong subsidence and faulting with the development of pelagic conditions (Karakitsios, 1995). This palaeogeographic evolution is recorded in the pelagic

XLVII. No $2-826$ 
Siniais Limestone and the laterally equivalent Louros Limestones of Pliensbachian age (Karakitsios and Tsaila-Monopolis, 1988; Dommergues et al., 2002; Karakitsios, 1992).

The initial formation of the Ionian Basin was followed by an internal differentiation into smaller sub-basins with half-graben geometry; in most cases these sub-basins did not exceed $5 \mathrm{~km}$ across (Karakitsios, 1995). This had as a result abrupt changes in thickness of the syn-rift formations, which take the shape of syn-sedimentary wedges. In the deeper parts of the half-grabens, these wedges include complete Toarcian-Tithonian successions, while in the elevated parts of the halfgrabens; the succession is interrupted by unconformities (Karakitsios, 1992, 1995). The directions of syn-sedimentary structures (e.g. slumps and syn-sedimentary faults) indicate that deposition was controlled both by structures formed during extension related to the opening of the Neotethys Ocean and the halokinesis of evaporites at the base of the Ionian Zone succession (Karakitsios, 1992, 1995). In the Early Berriasian the post-rift sequence began with the pelagic Vigla Limestone, whose deposition was effectively synchronous throughout the Ionian Basin (Karakitsios et al. 1988; Karakitsios, 1992; Karakitsios and Koletti, 1992). The Vigla Limestone blankets the synrift structures and, in some cases, directly overlies pre-rift units (e.g. Pantokrator Limestone). As a consequence, the base of the Vigla Limestone represents the break-up unconformity of the post-rift sequence in the Ionian Basin (Karakitsios, 1992). Long-standing differential subsidence during the deposition of the Vigla Limestone, as shown by the marked variation in the thickness of this formation, was probably due to the continued halokinesis of the basal-Ionian Zone evaporites. This palaeogeographic configuration persisted with minor off- and onlap movements along the basin margin until the Late Eocene, when orogenic movements and flysch sedimentation began. The particular geometry of the restricted sub-basins that were formed during the syn-rift period of the Ionian Zone may have favored increased organic-matter burial during the Toarcian-Tithonian interval (Baudin et al. 1990; Karakitsios, 1995; Rigakis and Karakitsios, 1998; Karakitsios and Rigakis, 2007). Toarcian black shales in the Ionian Zone were described first by Renz (1910), who compared them with the Posidonienschiefer of Germany, and sedimentological details were given by Walzebuck (1982). In this paper we demonstrate that the Lower Toarcian organic-rich laminated black shales, deposited in the different palaeogeographic environments of the Ionian sub-basins, record a global rather than a local event.

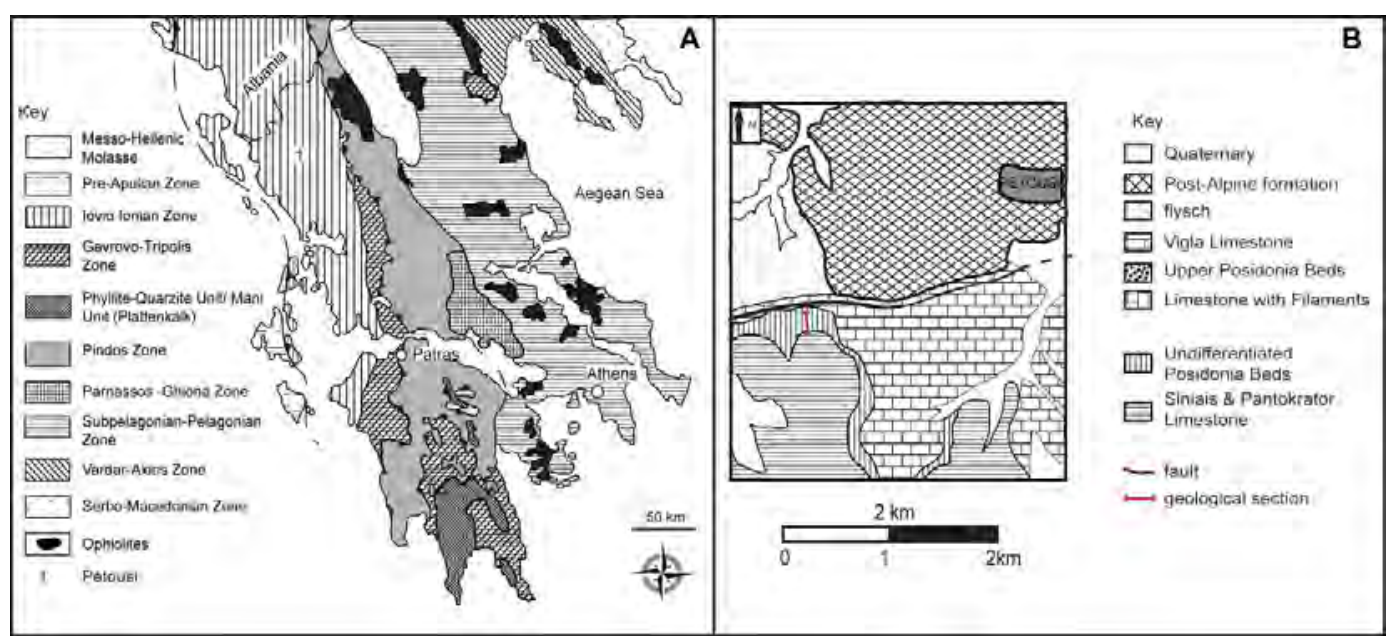

Figure 1 - A: structural map of Greece, B: geological map of the Petousi section.

\subsection{Petousi Section}

The Petousi section $\left(39^{\circ} 30^{\prime} \mathrm{N}, 2^{\circ} 35^{\prime} \mathrm{E}\right)$, was first described by Karakitsios (1992). It is located around $2 \mathrm{~km}$ WSW from Petousi village, south of the Petousi-Paramithia road, in Thesprotia prefecture. The studied outcrop is of excellent quality even though it is locally covered by vegetation. 
The section begins with the uppermost metres of the Siniais Limestone: white to grey limestones, with thin layers of black shales intercalations. It continues with the Undifferentiated Posidonia Beds, which begins with $10 \mathrm{~m}$ of black shales followed by a yellow-green chert rich in Posidonia (Bositra buchi).

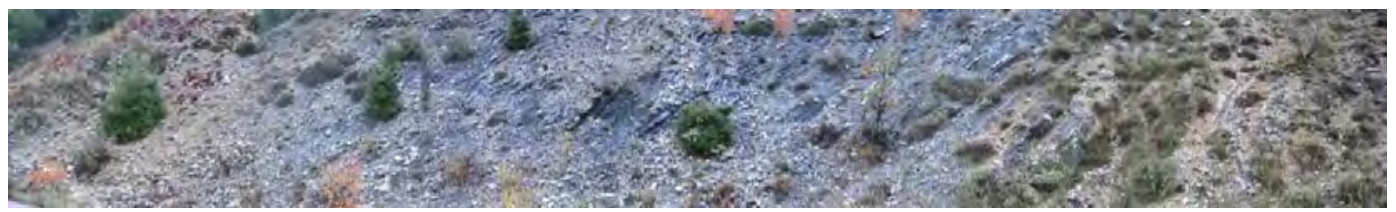

Figure 2 - Petousi section.

\section{Materials and Methods}

A total of 139 samples from Petousi, were analysed for their wt $\%$ TOC using a direct combustion and automatic titration method through a Strohlein Coulomat 702 analyser. Duplicate samples were used; one of them was roasted at $420^{\circ} \mathrm{C}$ overnight to remove organic carbon. Both samples were then combusted at $1220^{\circ} \mathrm{C}$ to decompose the calcium carbonate. The gaseous products of combustion are released (a Urea Peroxide tablet is removing $\mathrm{SO}_{2}$ ) and fed to barium perchlorite solution at stable temperature $10^{\circ} \mathrm{C}$ and $\mathrm{pH} 10$ with resultant change in $\mathrm{pH}$. An electrolytically titration is bringing the $\mathrm{pH}$ back to the original value. The quantity of electricity needed for this purpose gave an absolute determination of the amount of carbon present. The difference between the samples that had $\left(C_{a}\right)$ and had not $\left(C_{b}\right)$ been roasted at $420^{\circ} \mathrm{C}$ gave a measure of the value of TOC. Reproducibility of the samples was usually better than $0.1 \%$. The result was given in counts and the following formula was used for the final result.

\section{Equation 1}

$$
\% C=\frac{\text { counts } \times 0.2}{\text { weight }(m g)} \quad \% \text { TOC }=\% C a-\% C b
$$

For carbonate carbon-isotope composition, 211 bulk sediment samples were analysed. The powdered samples were cleaned using $10 \% \mathrm{H}_{2} \mathrm{O}_{2}$ followed by acetone $\left(\left(\mathrm{CH}_{3}\right)_{2} \mathrm{CO}\right)$ and then dried at $60^{\circ} \mathrm{C}$ for at least 30 minutes. Samples were then reacted with purified orthophosphoric acid at $90^{\circ} \mathrm{C}$ and analysed on-line using a VG Isogas and Prism II mass spectrometer. Corrections were applied and the results are reported through the $\delta$ notation, in \%o deviation from the Pee Dee Belemnite (PDB) standard. The calibration of the PDB was performed via the laboratory standard that was calibrated against NBS19 and Cambridge Carrara marble. Reproducibility of replicate analyses of the standards was usually better than $0.1 \%$.

\section{Equation 2}

$$
\delta X=\frac{R x(\operatorname{sample})-R x(\operatorname{stan} d a r d)}{R x(s \tan d a r d)} \times 1000
$$

For 97 samples organic carbon-isotope composition was calculated. The samples were decarbonated using $3 \mathrm{M} \mathrm{HCL}$ for the removal of $\mathrm{CaCO}_{3}$ and put in a warm surface for the removal of the rest $\mathrm{CO}_{3}{ }^{2-}$ for 8 hours. Samples were then rinsed with distilled water, centrifuged and rinsed again until $\mathrm{pH}$ was neutral and then dried in an oven at $60^{\circ} \mathrm{C}$. A quantity of 4 to $50 \mathrm{mg}$ (depending on the amount of organic carbon) was weighed out into a $8 \times 6 \mathrm{~mm}$ tinfoil cup and placed in an Europa Scientific Limited CN biological sample converter connected to a 20-20 stable isotope gas ratio mass spectrometer. Carbon isotope ratios were measured against a laboratory nylon standard $\left(\delta^{13} \mathrm{C}=-26.1 \pm 0.2 \%\right.$ and $)$ and expressed relative to Peedee belemnite (PDB) and reported through the $\delta$ notation. Reproducibility is better that $\pm 0.2 \%$. All the above analyses were undertaken at the University of Oxford. 
A set of 24 samples was investigated for the content of calcareous nannofossils. Smear-slides were prepared from the powdered rock according to the technique described in Bown \& Young (1998), then analyzed in an optical polarizing Leitz microscope at x1250. Nannofossils were counted for each sample in a surface area of the slide varying between 2 and $3 \mathrm{~cm}^{2}$ at the Laboratoire de Géologie de Lyon, Université Claude Bernard.

\section{Results}

\subsection{Biostratigraphy}

The samples that were studied from Petousi section show a diverse and relatively rich nannofossil assemblage, although preservation is moderate to poor. Schizosphaerella, M. jansae and some small Lotharingius (L. hauffi and L. frodoi) are the dominant forms in the assemblage. In the base of the section, corresponding to the Siniais Limestone, NJT 5b Subzone was identified based on the presence of Calyculus spp. and L. sigillatus. This zone spans the Pliensbachian/Toarcian boundary (Mattioli \& Erba, 1999). Higher in the section, the NJT 6 Zone is identified; starting at $5.4 \mathrm{~m}$ with the FO of $C$. superbus and ending at $9.8 \mathrm{~m}$ with the FO of $D$. striatus that marks the onset of the NJT 7 Zone.

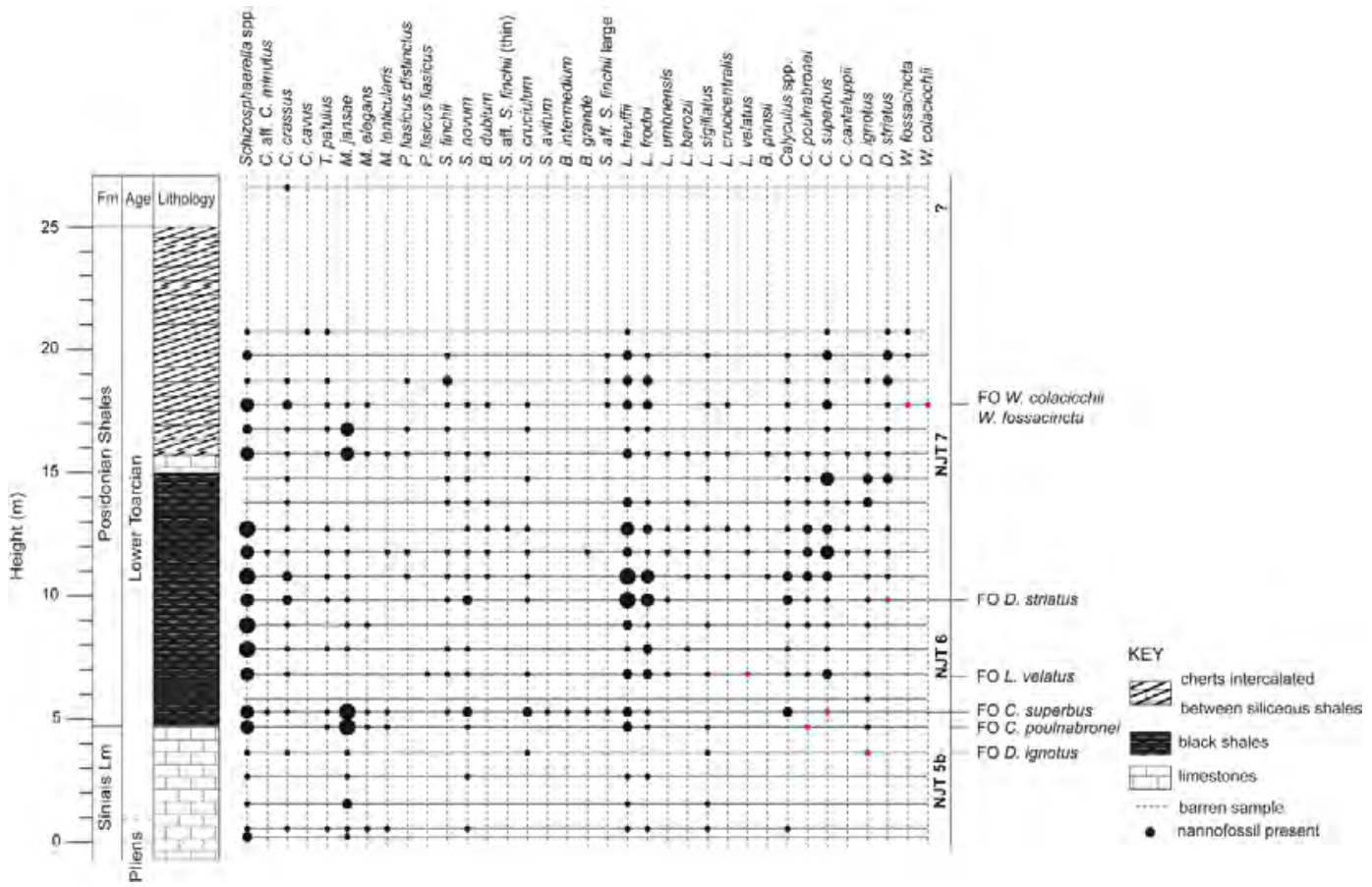

Figure 3 - Calcareous nannofossil biostratigraphy of Petousi section. Relative abundance per square surface unit was estimated. Four abundance classes were defined: rare, frequent, common and abundant. These classes are represented by a different size of black dots.

\subsection{Chemostratigraphy}

\subsubsection{Wt\% Total Organic Carbon (TOC)}

TOC values in the Siniais Limestone begin at very low values, $\sim 0-1 \mathrm{wt} \%$. In the basal Undifferentiated Posidonia Beds, where there are black shales, TOC values begin to rise marking a positive excursion that reaches values up to $4.86 \mathrm{wt} \%$ over a 2 -metre interval. Higher in the section, values are lower and fluctuate between $\sim 0$ and $3 \mathrm{wt} \%$. 


\subsubsection{Carbon-Isotope Ratio}

In Figure 3 it can be seen that both carbonate and organic-carbon $\delta^{13} \mathrm{C}$ profiles show a small disturbance at the 2-metre level of the section. This, together with the small excursion in the TOC data and the biostratigraphy, designate that this is the Pliensbachian/Toarcian boundary. Upsection, isotopic values of bulk carbonate remain stable around $1.3 \%$. The values show a marked $1 \%$ decrease, that spans less than $1 \mathrm{~m}$, half a metre above the NJT 5b/NJT 6 boundary. Above this level and for 11 metres, values increase recording a positive excursion of only $\sim 1 \%$. Higher in the section, values decrease again.

Above the Pliensbachian/Toarcian boundary $\delta^{13} \mathrm{C}_{\text {org }}$ fluctuates around a background value of $-29 \%$. At the NJT5b/NJT6 boundary, values fall and define the negative excursion that spans 2 metres of the section where values drop to $-33 \%$. Following this excursion, values begin to rise reaching values up to $-30 \%$. Up-section, values goes up and down until the 9.5 -metre level of the section. At this point a positive excursion that lasts for 2 metres and reaches values up to $\sim-26 \%$ is recorded. Above this level, $\delta^{13} \mathrm{C}_{\text {org }}$ attains background values ( $\left.\sim 29 \%\right)$ to the top of the section.
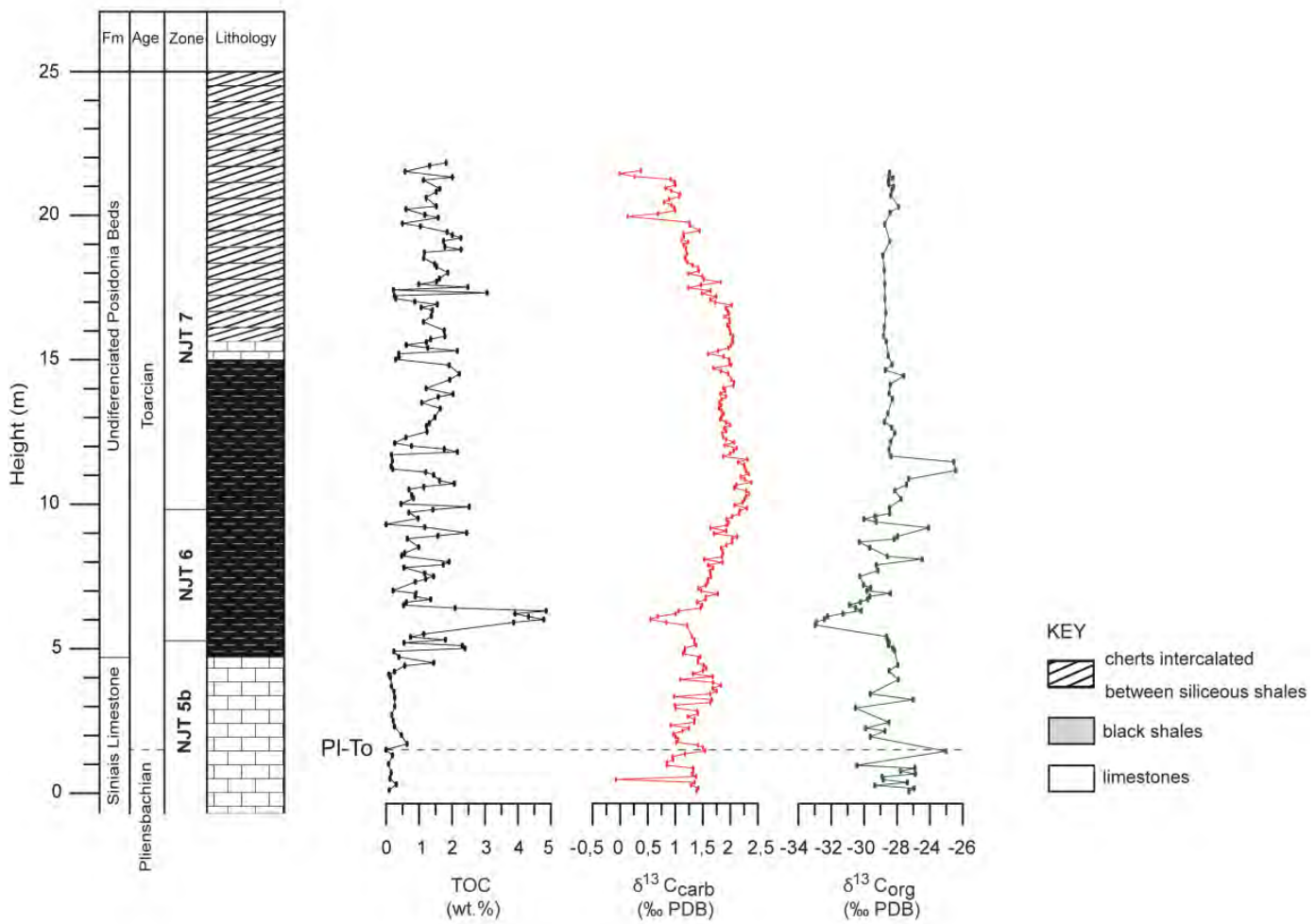

Figure 4 - Lithostratigraphic $\log$, bulk TOC, $\delta^{13} \mathrm{C}_{\text {carb }}$, and $\delta^{13} \mathrm{C}_{\text {org }}$ profiles through Petousi section.

\section{Discussion}

Calcareous nannofossil analysis from the Petousi section reveals the age of the studied formations. The Upper part of the Siniais Limestone belongs to Subzone NJT 5b Lotharingius sigillatus, spanning the Late Pliensbachian-basal Toarcian interval (Mattioli and Erba, 1999; Mattioli et al., 2009). The small negative followed by a small positive excursion in carbonate carbon-isotopic data in the same formation, confirms that there is the Pliensbachian-Toarcian boundary. The small negative 
carbon-isotope excursion probable represent a global event, since it has been recorded in many areas (Bodin et al., 2010; Hesselbo et al., 2007; Kafousia et al., 2011; Littler et al., 2010; Sabatino et al., 2009).

The lower part of the overlying stratigraphic formation (Undifferentiated Posidonia Beds) belongs to the Nannofossil Zone NJT 6 Carinolithus superbus. This Zone is encapsulated in the ammonite zones polymorphum/tenuicostatum and levisoni/serpentinus in Tethyan sections where ammonite biostratigraphy is available (Mattioli and Erba, 1999; Mattioli et al., 2009).

Total organic carbon values in the Petousi section from the Ionian Zone are comparable with coeval Tethyan sections. TOC values over the interval of the negative carbon-isotope excursion reach values up to $\sim 5 \%$. These values are similar to those in certain pelagic sections from the Southern Alps of Italy (Jenkyns, 2010; Jenkyns et al., 2001; Pancost et al., 2004).

In the Petousi section the negative carbon-isotope excursion and the increase in TOC, that are the main characteristics of the Toarcian Oceanic Anoxic Event, take place in the NJT 6 zone. The difference in this section, compared to sections from the Pindos Zone (Kafousia et al., 2011), is that in the NJT 7 zone is recorded a positive excursion, in both organic and carbonate carbon isotopes.

All the above data indicate that the Toarcian Oceanic Anoxic Event took place in the Ionian Zone but sedimentation and the geochemistry of seawater has been affected by local palaeoenviromental conditions.

\section{Acknowledgments}

The authors would like to thank Dr Norman Charnley and Mr Steve Wyatt (Earth Sciences Department) and Dr Peter Ditchfield (Archaeological Research Laboratory) for analyses performed during a visit of NK to Oxford University. NK would acknowledge the European Association of Organic Geochemists (EAOG) for the travel scholarship, which she received; and the University of Athens SARG for co-funding the field work.

\section{References}

Al-Suwaidi A.H., Angelozzi G.N., Baudin F., Damborenea S.E., Hesselbo S.P., Jenkyns H.C., Manceñido M.O. and Riccardi A.C. 2010. First record of the Early Toarcian Oceanic Anoxic Event from the Southern Hemisphere, Neuquén Basin, Argentina, Journal of the Geological Society, 167, 633-636.

Aubouin J. 1959. Contribution a 1 'étude géologique de la Grece septentrionale; les confins de l'Epire et de la Thessalie, Annales Géologiques des Pays Helléniques, 10.

Bailey T.R., Rosenthal Y., McArthur J.M. and van der Schootbrugge B. 2003. Paleoceanographic changes of the Late Pliensbachian-Early Toarcian interval: a possible link to the genesis of an Oceanic Anoxic Event, Earth and Planetary Science Letters, 212, 307-320.

Baudin F., Herbin J.P., Bassoulet J.P., Dercourt J., Lachkar G., Manivit H. and Renard M. 1990. Distribution of organic matter during the Toarcian in the Mediterranean Tethys and Middle East, In Huc, A.Y. (Ed.), Deposition of organic facies.73-92, American Association of Petroleum Geologists, Studies in Geology, 30, 73-92.

Bernoulli D. and Renz O. 1970. Jurassic carbonate facies and new ammonite faunas from Western Greece, Eclogae Geologicae Helvetiae, 63/2, 573-607.

Bodin S., Mattioli E., Fröhlich S., Marshall J.D., Boutib L., Lahsini S. and Redfern J. 2010. Toarcian carbon isotope shifts and nutrient changes from the Northern margin of Gondwana (High Atlas, Morocco, Jurassic): Palaeoenvironmental implications, Palaeogeography, Palaeoclimatology, Palaeoecology, 297, 377-390.

Bown P.R. and Young J. 1998. Chapter 2: techniques. In Bown, P.R. (Ed.), Calcareous Nannofossil Biostratigraphy, 17, Dordrecht, Kluwer Academic Publishing, 314 pp. 
Cohen A.S., Coe A.L. and Kemp D.B. 2007. The Late Palaeocene-Early Eocene and Toarcian (Early Jurassic) carbon isotope excursions: a comparison of their time scales, associated environmental changes, causes and consequences, Journal of the Geological Society, 164, 1093-1108.

Dommergues J.-L., Karakitsios V., Meister C. and Bonneau M. 2002. New ammonite data about the earliest syn-rift deposits (Lower Jurassic) in the Ionian Zone of N-W Greece (Epirus), Neues Jahrbuch fuer Geologie und Palaeontology, Abhandlungen, 223, 299-316.

IGRS-IFP 1966. Etude géologique de l'Epire (Grèce nord-occidentale), 306.

Gill B.C., Lyons T.W. and Jenkyns H.C. 2011. A global perturbation to the sulfur cycle during the Toarcian Oceanic Anoxic Event, Earth and Planetary Science Letters, 312, 484-496.

Hermoso M., Minoletti F., Rickaby R.E.M., Hesselbo S.P., Baudin F. and Jenkyns H.C. 2012. Dynamics of a stepped carbon-isotope excursion: Ultra high-resolution study of Early Toarcian environmental change, Earth and Planetary Science Letters, 319-320, 45-54.

Hesselbo S.P., Grocke D.R., Jenkyns H.C., Bjerrum C.J., Farrimond P., Morgans Bell H.S. and Green O.R. 2000. Massive dissociation of gas hydrate during a Jurassic oceanic anoxic event, Nature, 406, 392-395.

Hesselbo S.P., Jenkyns H.C., Duarte L.V. and Oliveira L.C.V. 2007. Carbon-isotope record of the Early Jurassic (Toarcian) Oceanic Anoxic Event from fossil wood and marine carbonate (Lusitanian Basin, Portugal), Earth and Planetary Science Letters, 253, 455-470.

Hönisch B., Ridgwell A., Schmidt D.N., Thomas E., Gibbs S.J., Sluijs A., Zeebe R., Kump L., Martindale R.C., Greene S.E., Kiessling W., Ries J., Zachos J.C., Royer D.L., Barker S., Marchitto T.M., Moyer R., Pelejero C., Ziveri P., Foster G.L. and Williams B. 2012. The Geological Record of Ocean Acidification, Science, 335, 1058-1063.

Jenkyns H.C. 1988. The early Toarcian (Jurassic) anoxic event; stratigraphic, sedimentary, and geochemical evidence, American Journal of Science, 288, 101-151.

Jenkyns H.C. 2003. Evidence for rapid climate change in the Mesozoic-Palaeogene greenhouse world, Phil. Trans. R. Soc. Lond. A, 361, 1885-1916.

Jenkyns H.C. 2010. Geochemistry of oceanic anoxic events, Geochemistry Geophysics Geosystems, 11, doi:10.1029/2009GC002788.

Jenkyns H.C. and Clayton C.J. 1986. Black shales and carbon isotopes in pelagic sediments from the Tethyan Lower Jurassic, Sedimentology, 33, 87-106.

Jenkyns H.C., Gröcke D.R. and Hesselbo S.P. 2001. Nitrogen isotope evidence for water mass denitrification during the Early Toarcian (Jurassic) Oceanic Anoxic Event, Paleoceanography, 16, 593-603.

Kafousia N., Karakitsios V., Jenkyns H.C. and Mattioli E. 2011. A global event with a regional character: the Early Toarcian Oceanic Anoxic Event in the Pindos Ocean (northern Peloponnese, Greece), Geological Magazine, 148, 619-631.

Karakitsios V. 1992. Ouverture et inversion tectonique du bassin Ionien (Epire, Grèce), Annales Géologiques des Pays Helléniques, 35, 185-318.

Karakitsios V. 1995. The influence of preexisting structure and halokinesis on organic matter preservations and thrust system evolution in the Ionian basin, Northwest Greece, American Association of Petroleum Geologists Bulletin, 79, 960-980.

Karakitsios V., Danelian T. and De Weve, P. 1988. Datations par les Radiolaires `a Filaments, Schistes `a Posidonies superierieurs et Calcaires de Vigla (zone Ionienne, Epire, Gr`ece) du Callovien au Tithonique terminal, C. R. Acad. Sci. Paris, 306, 367-372.

Karakitsios V., Kafousia N. and Tsikos H. 2010. A Review of Oceanic Anoxic Events as recorded in the Mesozoic sedimentary record of mainland Greece, Hell. J. of Geosc., 45, 123-132.

Karakitsios V. and Koletti L. 1992. Critical revision of the age of the basal Vigla Limestones (Ionian Zone, Western Greece), based on nannoplankton and calpionellids, with paleogeographical consequences, in: Hamersmid B., Young J. (Eds.), Proceedings of the fourth international nannoplankton association conference, Knihovnika Zemniho Plynu a Nafty, Prague, pp. 165-177. 
Karakitsios V. and Rigakis N. 2007. Evolution and Petroleum potential of Western Greece, Journal of Petroleum Geology, 30, 197-218.

Karakitsios V. and Tsaila-Monopolis S. 1988. Données nouvelles sur les niveaux supériers (Lias inférieur-moyen) des Calcaires de Pantokrator (zone Ionienne moyenne, Epire, Grèce continenetale). Description des Calcaires de Louros, Revue de Micropaléntologie, 31, 49-55.

Laubscher H. and Bernoulli D. 1977. Mediterranean and Tethys, In: A.E.M. Nairn (ed.): The ocean margins, vol.: Structural history of the Mediterranean basins, 129-132.

Littler K., Hesselbo P.S. and Jenkyns H.C. 2010. A carbon-isotope perturbation at the Pliensbachian-Toarcian boundary: evidence fromthe Lias Group, NE England, Geological Magazine, 147, 181-192.

Little C.T.S. and Benton M.J. 1995. Early Jurassic mass extinction: A global long-term event, Geology, 23, 495-498.

Mattioli E. and Erba E. 1999. Synthesis of calcareous nannofossil events in Tethyean Lower and Middle Jurassic successions, Rivista Italiana di Paleontologia e Stratigrafia, 105, 343-376.

Mattioli E., Pittet B., Petitpierre L. and Mailliot S. 2009. Dramatic decrease of pelagic carbonate production by nannoplankton across the Early Toarcian anoxic event (T-OAE), Global and Planetary Change, 65, 134-145.

Newton R.J., Reeves E.P., Kafousia N., Wignall P.B., Bottrell S.H. and Sha J.G. 2011. Low marine sulfate concentrations and the isolation of the European epicontinental sea during the Early Jurassic, Geology, 39, 7-10.

Pancost R.D., Crawford N., Magness S., Turner A., Jenkyns H.C. and Maxwell J.R. 2004. Further evidence for the development of photic-zone euxinic conditions during Mesozoic oceanic anoxic events, Journal of the Geological Society of London, 161, 353-364.

Renz C. 1910. Stratigraphische Untersuchingen im griechischen Mesozoikum und Palaeozoikum, Jahrbuch d. k. k. geol. Reichsanstalt, 60, 421-636.

Rigakis N. and Karakitsios V. 1998. The source rock horizons of the Ionian Basin (NW Greece), Marine and Petroleum Geology, 15, 593-617.

Sabatino N., Neri R., Bellanca A., Jenkyns H.C., Baudin F., Parisi G. and Masetti D. 2009. Carbon-isotope records of the Early Jurassic (Toarcian) oceanic anoxic event from the Valdorbia (Umbria-Marche Apennines) and Monte Mangart (Julian Alps) sections: palaeoceanographic and stratigraphic implications, Sedimentology, 56, 1307-1328.

Suan G., Mattioli E., Pittet B., Mailliot S. and Lecuyer C. 2008. Evidence for major environmental perturbation prior to and during the Toarcian (Early Jurassic) oveanic anoxic event from the Lusitanian Basin, Portugal, Paleoceanography, 23, PA1202.

Trecalli A., Spangenberg J., Adatte T., Föllmi K.B. and Parente M. 2012. Carbonate platform evidence of ocean acidification at the onset of the early Toarcian oceanic anoxic event, Earth and Planetary Science Letters, 357-358, 214-225.

van Breugel Y., Baas M., Schouten S., Mattioli E. and Sinninghe Damsté J.S. 2006. Isorenieratane record in black shales from the Paris Basin, France: Constraints on recycling of respired $\mathrm{CO} 2$ as a mechanism for negative carbon isotope shifts during the Toarcian oceanic anoxic event, Paleoceanography, 21, PA4220.

Walzebuck J.P. 1982. Bedding types of the Toarcian black shales in NW-Greece, In: Einsele G., Seilacher A. (Eds.), Cyclic and event stratification, Springer, 512-525 pp.

Wignall P.B. 2001. Large igneous provinces and mass extinctions, Earth-science reviews, 53, 133.

Woodfine R.G., Jenkyns H.C., Sarti M., Baroncini F. and Violante C. 2008. The response of two Tethyan carbonate platforms to the early Toarcian (Jurassic) oceanic anoxic event: environmental change and differential subsidence, Sedimentology, 55, 1011-1028. 